\title{
Diurnal roosts and minimum home range defined by sleeping sites of a thin-spined porcupine Chaetomys subspinosus (Rodentia: Erethizontidae)
}

\author{
Marlon Zortéa ${ }^{1,3} \&$ Bernardo F. A. de Brito²
}

\author{
1 Programa de Pós-Graduação em Ecologia e Evolução, Campus Jataí, Universidade Federal de Goiás. Rodovia BR 364 , km \\ 192, 75801 -615 Jataí, Goiás, Brazil. \\ 2 Bioma Mata Atlântica e Pampa, Diretoria de Unidades de Conservação de Proteção Integral, Instituto Chico Mendes de \\ Conservação da Biodiversidade. 70670-350 Brasília, Distrito Federal, Brazil. \\ ${ }^{3}$ Corresponding author. E-mail: mzortea@uol.com.br
}

\begin{abstract}
The thin-spined porcupine Chaetomys subspinosus (Olfers, 1818) is a species endemic to the extremely disturbed and fragmented Brazilian Atlantic forest. Little is known about its natural history. We analyzed the preferences of porcupine diurnal roost and home range, based on one relocated adult male that was radio-monitored during 1999. The individual was captured in the urban zone of Santa Teresa, Brazil, and relocated to a forest reserve $6 \mathrm{~km}$ from the capture site. The thin-spined porcupine feeds only on leaves. It prefers intermediate forest stratum (6-15 m of height) for roosting during daytime, generally using inclined branches with a diameter of 2 to $5 \mathrm{~cm}$. Most observations indicated a prehensile tail position. Home range was relatively large (15.81 ha) for an arboreal animal of this size and new areas were still being explored after five months of monitoring.
\end{abstract}

KEY WORDS. Atlantic forest; conservation; radio-tracking; roost; thin-spined porcupine; translocation.

The Atlantic Forest is a highly diverse biome that extends, almost continuously, from the northern state of the Rio Grande do Norte to the Rio Grande do Sul in Brazil. Its current size is less than $8 \%$ of its original area (Myers et al. 2000), distributed in fragments surrounded by cultivated areas and pastures. This extensive habitat loss of the Atlantic forest has left many species at risk, due to the reduction of their home range and fragmentation of their habitat. This issue is especially critical when considering endemic, naturally rare species, such as the endangered thin-spined porcupine.

Chaetomys subspinosus (Olfers, 1818) is an arboreal rodent endemic to the Brazilian Atlantic forest. Its distribution is restricted to eastern Brazil from south Sergipe through eastern Bahia, to northeast Minas Gerais and Espírito Santo and the extreme north of Rio de Janeiro (Oliver \& SANTOS 1991). Current populations are confined to a smaller area between southern Bahia and northern Espírito Santo (Chiarello et al. 1997).

The conservation status of C. subspinosus is unclear due to its low abundance in the nature and the lack of data on its natural history. Chaetomys subspinosus is listed as a globally threatened species in the Vulnerable category (B1 ab) with a declining population (IUCN 2008). It is also on the official list of threatened animals in Brazil, again in the vulnerable category (MACHADo et al. 2005).

Field studies of the species are rare. Chiarello et al. (1997) reported the nocturnal activity pattern and habitat use, and recently, Souto-Lima et al. (2009) presented substantial data on the diet of this species. There is currently a management program for this species financed by the Brazilian government, including genetic studies (Oliverra et al. 2007). Based on one radio-monitored animal in a southeastern Brazilian forest, we present new data on its home range and diurnal roosts.

\section{MATERIAL AND METHODS}

Santa Teresa is a small hilly city in the state of Espírito Santo, Brazil at $650 \mathrm{~m}$ elevation (ca. 20,000 inhabitants). It is bordered by many forest and agricultural fields that are predominantly coffee plantations. Most of the preserved forest is located within conservation units which include areas of difficult access for agricultural use. There are many forest fragments located close to the urban zone, and some mammals can be regularly found in orchards and backyards; among these, the porcupines C. subspinosus and Sphiggurus cf. villosus, and the maned sloth Bradypus torquatus Illiger, 1811 (M. ZoRTéA pers. obs., Chiarello et al. 2004).

This study was carried out at the Santa Lúcia Biological Station (SLBS) $\left(19^{\circ} 57^{\prime} \mathrm{S}, 40^{\circ} 32^{\prime} \mathrm{W}\right)$, a small 440 ha reserve owned by the federal government and administered by the Museu de Biologia Prof. Mello Leitão (Mendes \& Padovan 2000). Including neighboring forested areas, the chunk of native vegetation in which the SLBS is inserted comprises about 900 ha (SRBEKAraujo \& Chiarello 2007). The SLBS area is classified as a dense ombrophilous forest (IBGE 1994) and has one of the richest di- 
versity of plants in the world (Thomaz \& Monteiro 1997). The most diverse and abundant families are Myrtaceae, Lauraceae, and Sapotaceae (Thомаz \& Monteiro 1997). The canopy is not well-defined but has a high density of tree crowns between 5 and $15 \mathrm{~m}$ above the ground, with some emergents up to $35 \mathrm{~m}$ in height (Chiarello et al. 2004).

The altitude ranges from 550 to $950 \mathrm{~m}$. The annual average temperature in the reserve is $19.9^{\circ} \mathrm{C}$, with a minimum and maximum annual average temperature of 14.3 and $26.2^{\circ} \mathrm{C}$, respectively. The annual average precipitation is $1868 \mathrm{~mm}$. For more details concerning the SLBS, refer to Mendes \& Padovan (2000).

This work started with the capture of an adult thin-spined porcupine male found in the urban zone of Santa Teresa on February 7, 1997, which was brought to Prof. Mello Leitão (Museu de Biologia). After a careful check up, the porcupine was sedated (Ketamine) and biometric data was collected. The animal was then fitted with a radio-collar (Wildlife Materials Inc.) and released into the SLBS, after complete recovery.

The study was carried out between February 7, 1997, when the animal was released, and June 20, 1997. During this time, we conducted 56 trips to SLBS in an attempt to locate the animal and to characterize its roosts. After release, the animal was followed until dusk. We tried to observe the animals' nocturnal behavior for three consecutive nights after release, but we were unsuccessful. The following four characteristics were recorded for each roost: a) height (0-5, 6-10, 11-15, 16-20, 21$25 \mathrm{~m}) ; \mathrm{b}$ ) diameter of the support where the animal rested b) diameter of the branches used as shelters (c) position of the substrate (vertical, horizontal or inclined); d) position of the tail while sleeping (prehensile or not). The Spearman-correlation coefficient was calculated to measure the correlation between distance moved and time elapsed (days).

The trees used as roosts were plotted on a 1:20.000 m scale map. All distances were measured with a 50-m measuring tape and a compass. Home ranges were estimated based on the location of the 56 roosting trees. With this information, we were able to calculate the average distance between roosts, excluding the days when the animal returned to the same tree to rest. Data was then used to calculate a minimum convex polygon through the extension of the Spatial Movement Analysis of the ARCVIEW 3.1 program (ESRI, ARC/INFO - Environmental Systems Research Institute, Incorporation, 380 New York Street, Redlands, CA, USA).

\section{RESULTS}

External measurements $(\mathrm{cm})$ and weight $(\mathrm{kg})$ of the specimen were: head-body length 63.5 ; length of tail 24.5 ; length of head 9.0; length of ear 2.3; length of hand with claw 5.0; length of hand without claw 4.2; length of forearm 7.1; length of arms 6.4; length of feet with claws 6.8; length of feet without claws 6.2; length of legs 14.2; and weight 1,380 .

The animal was released into the SLBS on February 7 ,
1997 at 1:30 pm and observed until 17:00 h. During this time, we noted the following activities: moving, 1:47'10"; grooming, 0:02'28"; feeding, 0:34'00", and resting, 1:06'22". Twohours and twenty-minutes after the release, the subject began to take leaves into the mouth, sometimes eating them. The following leaves were ingested: a Myrtaceae (4 minutes), the young leaves of a Leguminosae (24 minutes), and the leaves of an undetermined plant (6 minutes). After eating, the porcupine rested. The total horizontal distance travelled by the thinspined porcupine during $4.5 \mathrm{~h}$ was $42.36 \mathrm{~m}$.

The porcupine was not very active during the day staying on a given sleeping tree most of the time, performing a few short bouts of grooming and (more rarely) feeding on leaves of the roosting tree. Activity began at dusk (5:00 and 6:00 pm). Our attempts to conduct night observations were unsuccessful. Thin-spined porcupines are extremely difficult to see in the field due to their well-camouflaged coat and cryptic behavior. Our subject was seen between the canopy foliage, which made detailed observations difficult.

Our subject consistently chose intermediate heights in the forest as day roosts $(6-15 \mathrm{~m})$ (Fig. 1). It used inclined branches (Fig. 2) that had a diameter range of 2 to $5 \mathrm{~cm}$ (Fig. 3) more frequently. Most observations showed a prehensile tail position (61\%) except when the animal was on branches over $5 \mathrm{~cm}$ in diameter, which were too large to be grasped by the short tail.

Displacement between roosts each night varied between zero (no movement as the animal returned to the same tree to roost) and $58.84 \mathrm{~m}$, with a mean distance of $18.2 \mathrm{~m}$ (S.D. 14.5 $\mathrm{m})$. Although daily changes of roosting trees were frequent, there were five days when the animal returned to the same tree to roost. The largest distances between roosting trees were recorded during four of the first five days after release $(42.36,58.84,13.09$, 25.65 , and $46.87 \mathrm{~m}$, respectively), although no significant correlation was found between the distance traveled and the time elapsed since release $(r=0,318 ; p=0,149)$. After almost five months, the tagged animal still continued to explore new areas. The home range was estimated to be 15.81 ha.

\section{DISCUSSION}

Our observations revealed some characteristics of $C$. subspinosus. These characteristics include: folivorous diet, discrete behavior of slow movements in the canopy to foraging areas, and sleeping in trees during the day. This slow behavior may be related to the physiological implications of an almost exclusive folivorous diet. Other Neotropical porcupines include fruits and seeds in their diets (MONTGOMERY \& Lubin 1978, CHARLeSDOMINIQUe et al. 1981).

The preference for roosting on branches with a diameter range of 2 to $5 \mathrm{~cm}$ differed from that recorded for another individual in the same locality, which used branches and lianas of small diameters $(<2 \mathrm{~cm}$ : Chiarello et al. 1997). However, those observations were based on scans of sampling during night foraging. The results of CHIARELlo et al. (1997) on height 

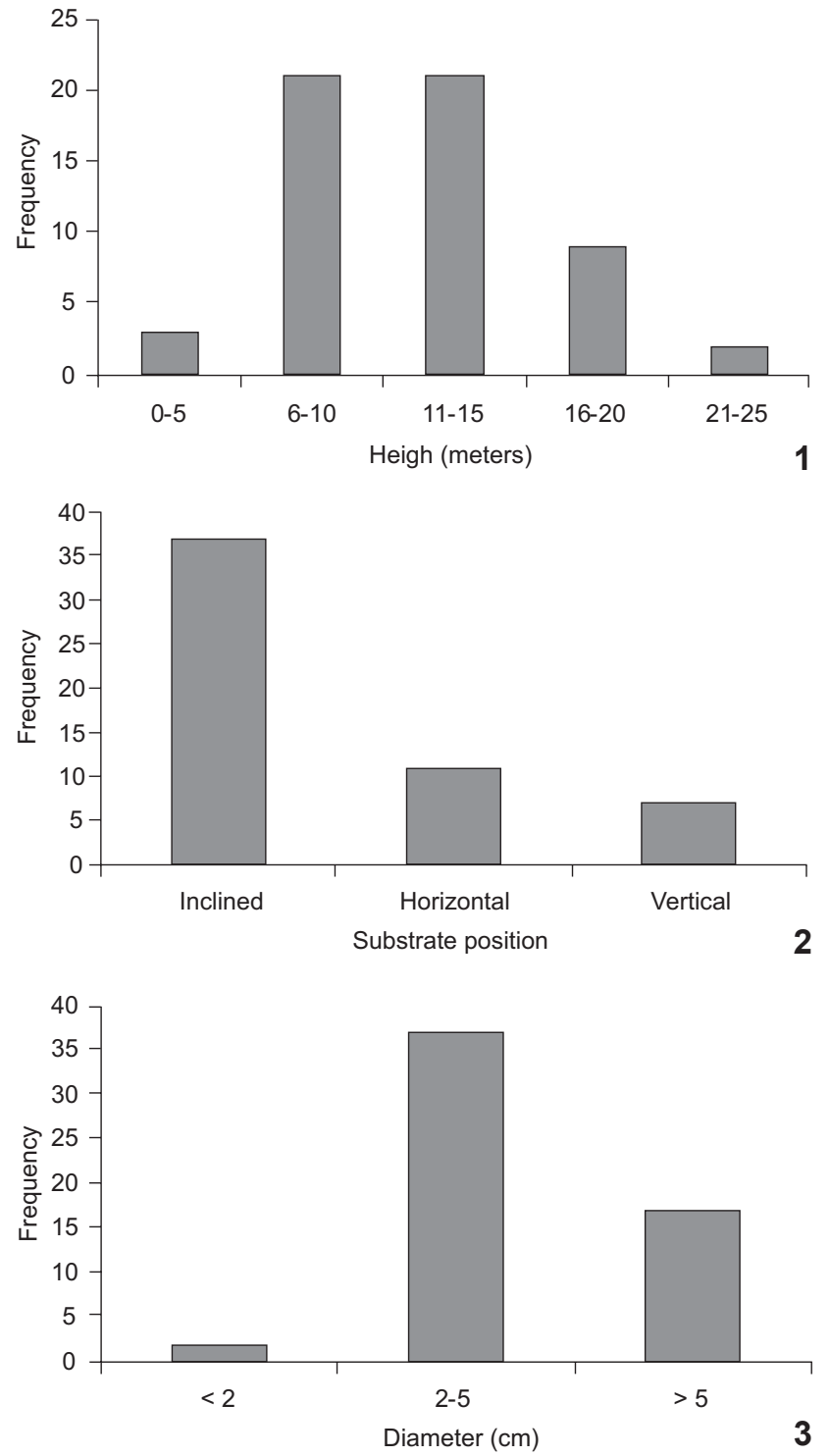

Figures 1-3. (1) Day roost preference of a C. subspinosus based on 15 roosts vertical stratification in Santa Lúcia Biological Station, southeastern Brazil; (2) substrate position of roosts used by a $C$. subspinosus; (3) diameter classes of braches used by C. subspinosus as resting supports.

and inclination of the substratum were similar to ours. Our observations also demonstrate that this species, like almost all erethizontids (North American Erethizon dorsatum (Linnaeus, 1758) is the only exception) (Woods 1973) uses the prehensile tail for support, especially when sleeping among smaller branches or lianas.

The roost-based home range was estimated to be 15.81 ha. However, this home range was not stable, possibly a conse- quence of stress translocation. Although the site where the animal was found and the SLBS, where the animal was relocated to, are similar in floristics and structure, it can be expected that the animal would engage in a more intensive exploration of an area during the first months in order to identify potential roosts and food supplies. Most likely, the home range of this lethargic species is smaller than that observed here. We recommend that long-term studies be conducted by radio-tracking individuals in their original home range to elucidate this question further. The occurrence of thin-spined porcupines in the urban area of Santa Teresa can be attributed to the natural dispersal of individuals confined to small forested fragments or to a response to a reduction in the size of the natural habitat, forcing them to explore new areas. Thus, the occurrence of Chaetomys and other mammals can be expected in an urban zone of Santa Teresa that is surrounded by forest fragments and forest islands.

This is the second individual successfully translocated to and radio monitored in the SLBS (Chiarello et al. 1997). An important observation from this and our earlier study was the tolerance of the C. subspinosus to translocation. The adaptation was likely facilitated by the similarity between the fragments surrounding Santa Teresa and the SLBS (climatic and floristic). This adaptability of C. subspinosus in two translocation studies is encouraging for its conservation and successful management programs are possible for this species.

\section{ACKNOWLEDGEMENTS}

We thank the Museu de Biologia Prof. Mello Leitão for logistic and financial support. Rogério Ribeiro and Clarice Bassi for helping with data collection. We also thank three anonymous reviewers that made helpful comments on the manuscript and Julie Shapiro who generously reviewed the English.

\section{LITERATURE CITED}

Charles-Dominique, P.; M. Atramentowicz; M. Charles-Dominique; H. Gerard; A. Hladik \& M.F. Prévost M. 1981. Les mammiferes frugivores arboricoles nocturnes dune forêt guyanaises: interrelations plantes-animaux. Revue d'Ecologie (La'Terre et La Vie) 35: 341-435.

Chiarello, A.G; M. Passamani \& M. Zortéa. 1997. Field observations on the thin-spined porcupine, Chaetomys subspinosus (Rodentia; Echimyidae). Mammalia 61: (1): 29-36.

Chiarello, A.G.; D.J. Chivers \& C. Bassi; M. A. Maciel; L. Moreira $\&$ M. Bazzalo. 2004. Translocation experiment for the conservation of maned sloths, Bradypus torquatus (Xenarthra, Bradypodidae). Biological Conservation 114 (4): 421-430.

IBGE. 1994. Mapa de Vegetação do Brasil. Rio de Janeiro, Fundação Instituto Brasileiro de Geografia e Estatística.

IUCN 2008. 2008 IUCN Red List of Threatened Species. Available online at: http://www.iucnredlist.org [Accessed: 11/X/2008]. 
Machado, A.B.M.; C.S. Martins \& G.M. Drummond. 2005. Lista da fauna brasileira ameaçada de extinção. Belo Horizonte, Fundação Biodiversitas, 160p.

Mendes, S.L. \& M.P. Padovan. 2000. A Estacão Biológica de Santa Lúcia, Santa Teresa, Espírito Santo. Boletim do Museu de Biologia Mello Leitão (Nova Série) 11-12: 7-34.

Montgomery, G.G. \& Y.D. Lubin. 1978. Movements of Coendou prehensilis in the Venezuelan llanos. Journal of Mammalogy 59 (4): 887-888.

Myers, N.; R.A. Mittermeier; C.G. Mittermeier; G.A.B. Fonseca \& J. Kent. 2000. Biodiversity hotspots for conservation priorities. Nature 403: 853-858.

Oliveira, C.G.; R.A. Martinez \& F.A. Gaiotto. 2007. DNA extraction from bristles and quills of Chaetomys subspinosus (Rodentia: Erethizontidae) using a novel protocol Genetics and Molecular Researchs 6 (3): 657-666.

Oliver, W.L.R. \& I.B. Santos. 1991. Threatened endemic mammals of the Atlantic forest region of Southeast Brazil. Wildlife Preservation Trust Special Science 4: 1-125.

Srbek-Araujo, A.C. \& A.G. Chiarello. 2007. Armadilhas fotográficas na amostragem de mamíferos: considerações metodológias e comparação de equipamentos. Revista Brasileira de Zoologia 24 (3): 647-656.

Souto-Lima, R.B.; P.A.Oliveira \& A.G. Chiarello. 2009. Diet of the thin-spined porcupine (Chaetomys subspinosus), an Atlantic forest endemic threatened with extinction in southeastern Brazil. Mammalian Biology doi:10.1016/ j.mambio.2009.09.002

Thomaz, L.D. \& R. Monteiro. 1997. Composição florística da Mata Atlântica de encosta da Estação Biológica de Santa Lúcia, município de Santa Teresa-ES. Boletim do Museu de Biologia Mello Leitão (Nova Série) 7: 3-48.

Woods, C.A. 1973. Erethizon dorsatum. Mammalian Species 29: 1-6.

Submitted: 06.V.2009; Accepted: 06.II.2010.

Editorial responsibility: Fernando de Camargo Passos

ZOOLOGIA 27 (2): 209-212, April, 2010 